\title{
Comparison of Hierarchical and Non-hierarchical Fuzzy Models with Simulation and an Application on Hypertension Data Set
}

\author{
Aşamalı ve Aşamalı Olmayan Bulanık Modellerin Simülasyon ve \\ Hipertansiyon Veri Seti Üzerinde Bir Uygulama ile Karşılaş̧ırılması
}

(D) Fulden Cantaş, (D) Imran Kurt Ömürlü, (D) Mevlüt Türe

Adnan Menderes University Faculty of Medicine, Department of Biostatistics, Aydın, Turkey

Keywords

Hierarchical, non-hierarchical, fuzzy model, classification, simulation, hypertension

Anahtar Kelimeler

Aşamalı, aşamalı olmayan, bulanık model, sınıflandırma, simülasyon, hipertansiyon

Received/Geliş Tarihi : 20.02.2017

Accepted/Kabul Tarihi : 02.05.2017

doi:10.4274/meandros.02996

Address for Correspondence/Yazışma Adresi: İmran Kurt Ömürlü PhD,

Adnan Menderes University Faculty of

Medicine, Department of Biostatistics, Aydın, Turkey

Phone : +902562253166

E-mail : ikurtomurlu@gmail.com

ORCID ID: orcid.org/0000-0003-2887-6656

(C) Meandros Medical and Dental Journal, Published by Galenos Publishing House.

This is article distributed under the terms of the

Creative Commons Attribution NonCommercial 4.0

International Licence (CC BY-NC 4.0).

\section{Abstract}

Objective: The aim of this study is to compare the classification performances of hierarchical and non-hierarchical fuzzy models built by using different membership functions.

Materials and Methods: In this study, normally distributed data sets containing different number of independent variables $(p=3$ and $p=6)$ were generated. Besides, the classification performances of hierarchical and non-hierarchical fuzzy models built by using the data set which contained body mass index, fasting blood glucose and triglyceride values of hypertensive $(n=206)$ and control $(n=113)$ people were compared.

Results: It was found that there was a significant difference between the fuzzy models $(p<0.001)$. According to the result of both simulation and hypertension data set application, non-hierarchical fuzzy models were found to have better classification performance than hierarchical fuzzy models according to sensitivity, specificity, accuracy and root mean square criteria. Moreover, when number of independent variables was increased, performances of the models increased too and approached to each other.

Conclusion: In fuzzy logic methods, data structure, distributions of the variables and correlation between them, how to divide independent variables into categories and which of the fuzzy logic methods is to choose should be examined by taking an expert support.

Öz

Amaç: Bu çalışmanın amacı farklı üyelik fonksiyonları ile oluşturulan aşamalı ve aşamalı olmayan bulanık modellerin sınıflandırma performanslarının karşılaştırılmasıdır.

Gereç ve Yöntemler: Bu çalışmada farklı sayıda $(p=3$ ve $p=6)$ bağımsız değişkenler içeren normal dağılıma uygunluk gösteren veri setleri türetildi. Ayrıca hipertansif $(n=206)$ ve kontrol $(n=113)$ bireylerine ilişkin beden kitle indeksi, açlık kan şekeri ve trigliserid değerlerini içeren veri seti kullanılarak oluşturulan aşamalı ve aşamalı olmayan bulanık modellerin sınıflandırma performansları karşılaştırıldı.

Bulgular: Bulanık modeller arasında ileri düzeyde farklılık olduğu bulundu $(p<0,001)$. Hem simülasyon hem de hipertansiyon veri seti sonuçlarına göre, aşamalı 
olmayan bulanık modellerin duyarlılık, özgüllük, doğruluk ve hata kareler ortalamasının karekökü kriterlerine göre aşamalı bulanık modellerden daha iyi sınıflandırma performansı gösterdiği tespit edildi. Bunun yanı sıra, bağımsız değişken sayısı artırıldığında modellerin performansları arttı ve birbirine yaklaştı.

Sonuç: Bulanık mantık yöntemlerinde veri yapısı, değişkenlerin dağılımı ve değişkenler arasındaki ilişki, bağımsız değişkenlerin kategorilere nasıl ayrılacağı ile hangi bulanık mantık yönteminin seçileceği uzman desteği alınarak irdelenmelidir.

\section{Introduction}

In scientific researches, examined events are defined by mathematical models. The mathematical models that are formed enable to interpret in which state the examined event will be in time. Since the statistical events cannot be interpreted absolutely, the case of transition of events from one to another occurs. In the study of this kind of problems fuzzy logic approach may be used (1).

Fuzzy logic structure is developed by an article entitled "Fuzzy Sets" written by Zadeh (2). While classical logic is dichotomous as $\{0,1\}$ and there is not any uncertainty; fuzzy logic enables the membership of an element to a fuzzy set to be any value in $[0,1]$ interval. Human thought structure utilizes events with approximate terms such as "a few", "many", "more" instead of the crisp terms such as "present", "absent" $(3,4)$. When viewed from this aspect, fuzzy logic represents the real world and human thought structure in a good way.

While non-hierarchical fuzzy models (NHFMs) are built by adding all independent variables to the model at the same time; HFMs are created by combining fuzzy sub-models having lower dimensions. In NHFM approach; as the number of independent variables increases, the number of rules that are used to make decision about dependent variable increases exponentially in knowledge base, which causes "curse of dimensionality" due to the fact that the number of adaptive parameters increases so much especially when there are too many independent variables (5). In order to overcome this problem, HFMs are suggested since the number of rules are linearly increases (5-8). The aim of this study is to compare the classification performances of HFMs and NHFMs using different membership functions.

\section{Materials and Methods}

\section{Adaptive Neuro-fuzzy Inference System (ANFIS)}

ANFIS is a non-hierarchical hybrid network structure which represents Sugeno fuzzy inference system (9-16). The rules of ANFIS structure are as follows $(8,11,17-21)$ :
Rule 1: If $X_{1}=A_{1}$ and $X_{2}=B_{1}$ then $\hat{Y}_{1}=f_{1}\left(X_{1}, X_{2}\right)=p_{1} X_{1}+q_{1} X_{2}+r_{1}$ Rule 2: If $X_{1}=A_{1}$ and $X_{2}=B_{2}$ then $\hat{Y}_{2}=f_{2}\left(X_{1}, X_{2}\right)=p_{2} X_{1}+q_{2} X_{2}+r_{2}$ Rule 3: If $X_{1}=A_{2}$ and $X_{2}=B_{1}$ then $\hat{Y}_{3}=f_{3}\left(X_{1}, X_{2}\right)=p_{3} X_{1}+q_{3} X_{2}+r_{3}$ Rule 4: If $X_{1}=A_{2}$ and $X_{2}=B_{2}$ then $\hat{Y}_{4}=f_{4}\left(X_{1}, X_{2}\right)=p_{4} X_{1}+q_{4} X_{2}+r_{4}$ ANFIS structure consists of 5 layers (Figure 1 ) (2224):

$\mathbf{1}^{\text {st }}$ layer, fuzzification layer: Each node in this layer is adaptive and outputs of the nodes consist of a membership degree depending on the membership function used and values of independent variables. The output $\mathrm{O}_{1, \mathrm{i}}$ of this node is calculated as follows:

$$
\begin{aligned}
& \mathrm{O}_{1, \mathrm{i}}=\mu_{\mathrm{Ai}}\left(\mathrm{X}_{1}\right), \mathrm{i}=1,2 \\
& \mathrm{O}_{1, \mathrm{i}}=\mu_{\mathrm{Bi}-2}\left(\mathrm{X}_{2}\right), \mathrm{i}=3,4
\end{aligned}
$$

To predict the parameters of this layer with the least error, backpropagation algorithm is used $(9,25,26)$.

$2^{\text {nd }}$ layer, rule layer: None of the nodes in this layer is adaptive and they are expressed as $\Pi$. Each node corresponds to the rules written according to Sugeno fuzzy inference system and the number of them. Outputs of each rule nodes $\mathrm{O}_{2, \mathrm{i}}$ show rule weights calculated by $(27,28)$ :

$$
\begin{aligned}
& \mathrm{O}_{2, i}=\mu_{A i}\left(X_{1}\right) * \mu_{B j}\left(X_{2}\right), i=1, j=1,2 \\
& O_{2, i}=\mu_{A i}\left(X_{1}\right) * \mu_{B j}\left(X_{2}\right), i=2, j=1,2
\end{aligned}
$$

$3^{\text {rd }}$ layer, normalization layer: All of the nodes in this layer are fixed. Each node gives normalized value of each rule $(29,30)$ :

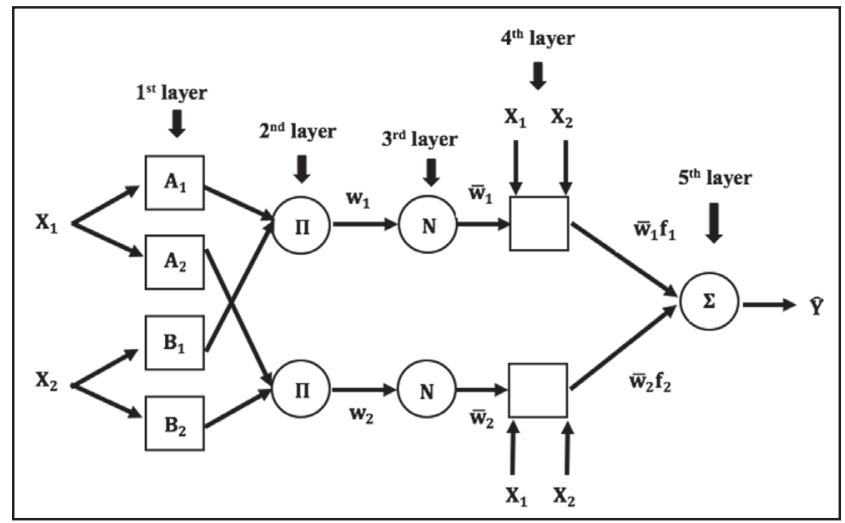

Figure 1. Adaptive neuro-fuzzy inference system structure 
$\mathrm{O}_{3, \mathrm{i}}=\overline{\mathrm{w}}_{\mathrm{i}}=\frac{\mathrm{w}_{\mathrm{i}}}{\sum_{\mathrm{i}} \mathrm{w}_{\mathrm{i}}}, \mathrm{i}=1,2,3,4$

$4^{\text {th }}$ layer, weighting layer: Each of the nodes $\mathrm{O}_{4, \mathrm{i}}$ in this layer, are adaptive and weighted output values of each rule are calculated. To predict the output parameters set $\left[p_{i}, q_{i}, r_{i}\right]$ of $i^{\text {th }}$ rule with minimum error, least squares estimation method is used $(16,31)$ :

$$
0_{4, i}=\bar{w}_{i} f_{i}=\bar{w}_{i}\left(p_{i} X_{1}+q_{i} X_{2}+r_{i}\right), i=1,2,3,4
$$

$5^{\text {th }}$ layer, aggregation layer: There is only one node in this layer and the node is fixed. Outputs of weighting layer are gathered in this layer and the real value of ANFIS system is obtained $(11,24)$ :

$$
\widehat{Y}=0_{5, i}=\sum_{i} \bar{w}_{i} f_{i}=\frac{\sum_{i} w_{i} f_{i}}{\sum_{i} w_{i}}, i=1,2,3,4
$$

\section{Hierarchical Fuzzy Model Structure}

Use of NHFMs in complex and high dimensional systems causes curse of dimensionality problem. HFMs are suggested to overcome this $(5,7)$.

The number of rules exponentially increases as the number of independent variables increases in NHFMs while it increases linearly in HFMs. Supposing that there are $m$ independent variables and each of these variables has $v$ membership functions, then the number of rules equals to $\mathrm{v}^{\mathrm{m}}$ in NHFMs while there are $\left[(m-1) * v^{2}\right]$ rules in HFMs $(6,7,32,33)$. Examining the HFM that has $v$ fuzzy sets and $m$ independent variables (Figure 2$)$, it is seen that intermediate outputs $\left(U_{1}, U_{2}, \ldots\right.$ $U_{m-2}$ ) and dependent variable $\hat{Y}=U_{m-1}$ are calculated by adding independent variables $\left(X_{1}, X_{2}, \ldots, X_{m}\right)$ to the model hierarchically.

\section{Simulation}

In simulation, normally distributed data sets were generated and the number of units was set to $n=1000$.

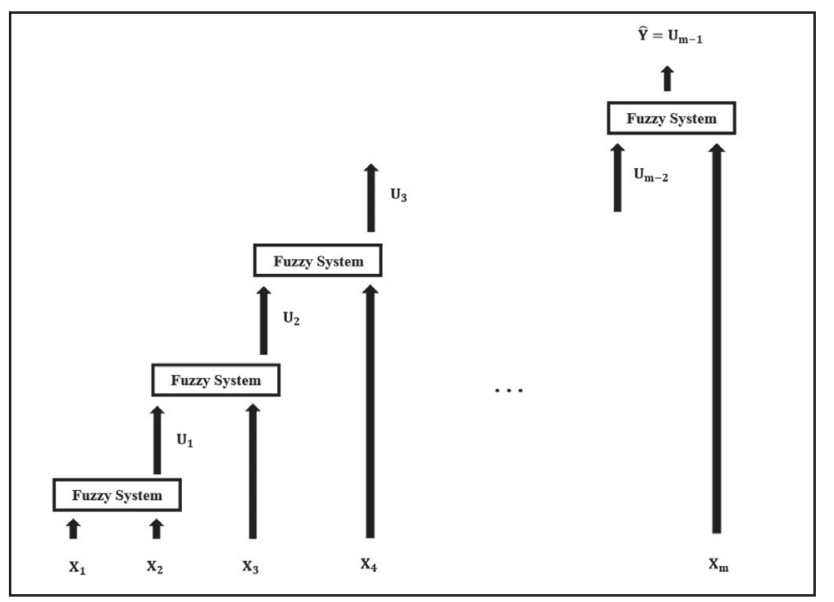

Figure 2. A hierarchical fuzzy model structure consisting of $(\mathrm{m}-1)$ fuzzy sub-models and $\mathrm{m}$ independent variables (32)
The data sets were randomly divided into 70\% (700 units) training and 30\% (300 units) test sets.

\section{Simulation with Three Independent Variables}

Independent variables were derived from normal distributions as being $X_{1} \sim N(200,45), X_{2} \sim N(130,30)$, $X_{3} \sim N(60,14)$ and correlated to one another $\left(r_{12}=0.704\right.$, $r_{13}=0.553, r_{23}=0.372$ ).

In training set, the most correlated independent variables $X_{1}$ and $X_{2}$ were added to a layer by creating a Sugeno fuzzy model (SFM) in both training and test sets, then intermediate output $U_{1}$ was obtained. After this, HFM was built by using $U_{1}$ and $X_{3}$. In this way, class prediction of dependent variable in test set was done.

When building NHFM, all the independent variables were used in ANFIS structure. Then the class prediction of dependent variable in test set was done running the created model.

\section{Simulation with Six Independent Variables}

Independent variables were generated as being $X_{1} \sim N(150,35), \quad X_{2} \sim N(110,25), \quad X_{3} \sim N(130,30)$, $x_{4} \sim N(100,15), \quad x_{5} \sim N(85,20), \quad x_{6} \sim N(50,10) \quad$ and correlated to one another $\left(r_{\min }=0,400-r_{\max }=0.900\right)$.

First, the most correlated independent variable pairs $X_{1}-X_{2}, X_{3}-X_{4}$ and $X_{5}-X_{6}$ were layered and the intermediate outputs $U_{1}, U_{2}$ and $U_{3}$ of each layer were obtained both in training and test sets. By compounding intermediate outputs, the HFM was constructed and class prediction of dependent variable in test set was done.

Table 1. Fuzzification of body mass index, triglyceride, fasting blood glucose and descriptive statistics (mean \pm standard deviation) of sub-groups

\begin{tabular}{|l|l|l|l|}
\hline $\begin{array}{l}\text { Independent } \\
\text { variables }\end{array}$ & Sub-groups & Mean \pm SD & Min-Max \\
\hline \multirow{3}{*}{ BMI $\left(\mathbf{k g} / \mathbf{m}^{2}\right)$} & Normal & $22.90 \pm 1.58$ & $18.10-24.80$ \\
\cline { 2 - 4 } & Overweight & $27.46 \pm 1.45$ & $25-29.80$ \\
\cline { 2 - 4 } & Obese & $32.36 \pm 1.92$ & $30-37.10$ \\
\hline \multirow{3}{*}{ TG $(\mathrm{g} / \mathrm{dL})$} & Normal & $103.74 \pm 26.39$ & $36-149$ \\
\cline { 2 - 4 } & High at limit & $173.02 \pm 13.97$ & $150-199$ \\
\cline { 2 - 4 } & High & $269.29 \pm 69.93$ & $200-478$ \\
\hline \multirow{2}{*}{ FG $(\mathbf{m g} / \mathbf{d L})$} & Hypoglycaemia & $65.56 \pm 2.18$ & $60-69$ \\
\cline { 2 - 4 } & Normal & $88.5 \pm 10.75$ & $70-110$ \\
\cline { 2 - 4 } & Hyperglycaemia & $114.67 \pm 2.86$ & $111-120$ \\
\hline
\end{tabular}

SD: Standard deviation, BMI: Body mass index, TG: Triglyceride, FBG: Fasting blood glucose, Min: Minimum, Max: Maximum 
All independent variables were used in ANFIS structure to construct NHFM and classes of each unit were predicted.

\section{Hypertension Data Set}

In order to construct fuzzy models, the variables fasting blood glucose (FBG) (mg/dL), body mass index (BMI) $\left(\mathrm{kg} / \mathrm{m}^{2}\right)$ and triglyceride $(\mathrm{TG})(\mathrm{g} / \mathrm{dL})$ which showed significant difference between hypertension and control groups, were correlated to each other and had fuzziness in their distributions were chosen as independent variables (34).

Each of the independent variables of hypertension data set was fuzzified by being divided into three subgroups. Mean \pm standard deviation and minimummaximum values (minimum-maximum) of each of the groups were calculated to predict fuzzy models (Table 1).

In the first step of hypertension data set application, data set was randomly separated into $70 \%$ (223 units) training and 30\% (96 units) test sets. The correlation coefficients between independent variables were $r_{\mathrm{BMI}-\mathrm{TG}}=0,842, \mathrm{r}_{\mathrm{TG}-\mathrm{FBG}}=0.210$ and $r_{\mathrm{BMI}}$ ${ }_{\mathrm{FBG}}=0.113$. In training set, SFM was constructed by using the most correlated variable pairs BMI-TG in the first layer of HFM. Then by using intermediate output $U_{1}$ of SFM and FBG as the independent variables of ANFIS structure, HFM was constructed.

In order to build NHFM structure, all the independent variables of training set and descriptive statistics (Table 1 ) of these variables were used in ANFIS structure.

Then classes of each unit of both training and test sets were predicted by adapting initial membership values of fuzzified variables to obtain minimum classification error.

\section{Results}

\section{Simulation}

The results showed that there was a significant difference $(p<0.001)$ between classification performances of NHFMs and HFMs based on sensitivity (\%), specificity (\%), accuracy (\%) and root mean square error (RMSE) (\%).

Comparison results of simulation with three independent (Table 2) and six independent (Table 3) variables showed that the sensitivity, specificity and accuracy rates of NHFMs were higher while RMSE was lower than HFMs in test set.

\section{Hypertension Data Set Application}

It was found in hypertension data set application that different membership functions resulted in different classification results. In test set, sensitivity (\%), specificity (\%) and accuracy (\%) rates were higher and RMSE (\%) was lower NHFMs than HFMs constructed by Gaussian membership function (Table 4).

Rule basis of hierarchical and NHFMs are as follows:

\section{Rule Base in Non-hierarchical Fuzzy Models}

Rule 1: If $\mathrm{BMI}_{\text {normal }}$ and $\mathrm{TG}_{\text {normal }}$ and $\mathrm{FBG}_{\text {hypoglycaemia }}$ then GROUP control

Rule 2: If $\mathrm{BMI}_{\text {normal }}$ and $\mathrm{TG}_{\text {normal }}$ and $\mathrm{FBG}_{\text {normal }}$ then GROUP ${ }_{\text {control }}$

Rule 3: If $\mathrm{BMI}_{\text {normal }}$ and $\mathrm{TG}_{\text {normal }}$ and $\mathrm{FBG}_{\text {hyperglycaemia }}$ then GROUP ${ }_{\text {control }}$

Rule 4: If $\mathrm{BMI}_{\text {normal }}$ and $\mathrm{TG}_{\text {high at limit }}$ and $F B G_{\text {hypoglycaemia }}$ then GROUP,

Rule 5: If $\mathrm{BMI}_{\text {normal }}^{\text {control }}$ and $\mathrm{TG}_{\text {high at limit }}$ and $\mathrm{FBG}_{\text {normal }}$ then GROUP ${ }_{\text {control }}$

Rule 6: If $B M I_{\text {normal }}$ and $\mathrm{TG}_{\text {high at limit }}$ and $\mathrm{FBG}_{\text {hyperglycaemia }}$ then GROUP,

Rule 7: If $\mathrm{BMI}_{\text {normal }}$ and $\mathrm{TG}_{\text {high }}$ and $\mathrm{FBG}_{\text {hypoglycaemia }}$ then GROUP

Rule 8: If $\mathrm{BMI}_{\text {normal }}$ and $\mathrm{TG}_{\text {high }}$ and $\mathrm{FBG}_{\text {normal }}$ then GROUP control

Rule 9: If $\mathrm{BMI} \mathrm{I}_{\text {normal }}$ and $\mathrm{TG}_{\text {high }}$ and $\mathrm{FBG}_{\text {hyperglycaemia }}$ then GROUP control

Rule 10: If $B \mathrm{BM}_{\text {overweight }}$ and $\mathrm{TG}_{\text {normal }}$ and $\mathrm{FBG}_{\text {hypoglycaemia }}$ then GROUP control

Rule 11: If $\mathrm{BMI}_{\text {overweight }}$ and $\mathrm{TG}_{\text {normal }}$ and $F B G_{\text {normal }}$ then GROUP ${ }_{\text {control }}$

Rule 12: If $\mathrm{BMI}_{\text {overweight }}$ and $\mathrm{TG}_{\text {normal }}$ and $\mathrm{FBG}_{\text {hyperglycaemia }}$ then GROUP control

Rule 13: If $\mathrm{BMI}_{\text {overweight }}$ and $\mathrm{TG}_{\text {high at limit }}$ and $F \mathrm{FG}_{\text {hypoglycaemia }}$ then GROUP control

Rule 14: If $B M l_{\text {overweight }}$ and $T G_{\text {high at limit }}$ and $F B G_{\text {normal }}$ then GROUP ${ }_{\text {control }}$

Rule 15: If $B M l_{\text {overweight }}$ and $T G_{\text {high at limit }}$ and $F B G_{\text {hyperglycaemia }}$ then GROUP, overweight

Rule 16: If $\mathrm{BMI} \mathrm{overweight}_{\text {and }} \mathrm{TG}_{\text {high }}$ and $\mathrm{FBG}_{\text {hypoglycaemia }}$ then GROUP ${ }_{\text {hypertension }}$

Rule 17: If $\mathrm{BMI}_{\text {overweight }}$ and $\mathrm{TG}_{\text {high }}$ and $\mathrm{FBG}_{\text {normal }}$ then GROUP ${ }_{\text {hypertension }}$

Rule 18: If $B M I_{\text {overweight }}$ and $\mathrm{TG}_{\text {high }}$ and $\mathrm{FBG}_{\text {hyperglycaemia }}$ then GROUP hypertension

Rule 19: If $B M I_{\text {obese }}$ and $\mathrm{TG}_{\text {normal }}$ and $F B G_{\text {hypoglycaemia }}$ then GROUP hypertension

Rule 20: If $\mathrm{BMI}_{\text {obese }}$ and $\mathrm{TG}_{\text {normal }}$ and $\mathrm{FBG}_{\text {normal }}$ then GROUP hypertension 
Rule 21: If $\mathrm{BMI}_{\text {obese }}$ and $\mathrm{TG}_{\text {normal }}$ and $\mathrm{FBG}_{\text {hyperglycaemia }}$ then GROUP ${ }_{\text {hypertension }}$

Rule 22: If $\mathrm{BMI}_{\text {obese }}$ and $\mathrm{TG}_{\text {high at limit }}$ and $\mathrm{FBG}_{\text {hypoglycaemia }}$ then GROUP hypertension

Rule 23: If $B M I_{\text {obese }}$ and $\mathrm{TG}_{\text {high at limit }}$ and $F B G_{\text {normal }}$ then GROUP ${ }_{\text {hypertension }}$
Rule 24: If $\mathrm{BMI}_{\text {obese }}$ and $\mathrm{TG}_{\text {high at limit }}$ and $\mathrm{FBG}_{\text {hyperglycaemia }}$ then GROUP ${ }_{\text {hypertension }}$

Rule 25: If $\mathrm{BMI}_{\text {obese }}$ and $\mathrm{TG}_{\text {high }}$ and $\mathrm{FBG}_{\text {hypoglycaemia }}$ then GROUP ${ }_{\text {hypertension }}$

Rule 26: If $\mathrm{BMI}_{\text {obese }}$ and $\mathrm{TG}_{\text {high }}$ and $\mathrm{FBG}_{\text {normal }}$ then GROUP ${ }_{\text {hypertension }}$

\begin{tabular}{|c|c|c|c|c|c|}
\hline Function & Model & Sensitivity & Specificity & Accuracy & RMSE \\
\hline \multirow[t]{2}{*}{ Bell } & NHFM & $97.78(96.15-98.66)$ & 97.45 (96.43-98.63) & $97.33(96.67-98.00)$ & $16.33(14.14-18.26)$ \\
\hline & HFM & 90.85 (88.96-92.93) & 90.57 (88.56-92.67) & $90.67(89.33-92.00)$ & $30.55(28.28-32.66)$ \\
\hline \multirow[t]{2}{*}{ Gauss* } & NHFM & $98.04(96.88-99.27)$ & 98.04 (96.91-99.26) & $98.00(97.33-98.33)$ & $14.14(12.91-16.33)$ \\
\hline & HFM & $91.16(89.14-93.06)$ & 90.85 (88.89-92.89) & $91.00(89.67-92.00)$ & $30.00(28.28-32.15)$ \\
\hline \multirow[t]{2}{*}{ Triangular* } & NHFM & 98.11 (97.11-99.31) & $98.12(97.08-99.31)$ & $98.00(97.33-98.67)$ & $14.14(11.55-16.33)$ \\
\hline & HFM & 91.56 (89.64-93.38) & 91.29 (89.40-93.29) & $91.33(90.33-92.67)$ & $29.44(27.08-31.09)$ \\
\hline \multirow[t]{2}{*}{ Trapezoidal $^{*}$} & NHFM & $97.90(96.56-98.70)$ & 97.90 (96.60-98.69) & $97.67(97.00-98.33)$ & $15.28(12.91-17.32)$ \\
\hline & HFM & $90.88(88.89-92.86)$ & $90.34(88.31-92.59)$ & 90.67 (89.33-91.67) & $30.55(28.87-32.66)$ \\
\hline
\end{tabular}

Table 3. Descriptive statistics [median (25th-75th percentiles)] of sensitivity, specificity, accuracy and root mean square error of hierarchical fuzzy models and non-hierarchical fuzzy models and their comparison results with six independent variables in test set

\begin{tabular}{|c|c|c|c|c|c|}
\hline Function & Model & Sensitivity & Specificity & Accuracy & RMSE \\
\hline \multirow[t]{2}{*}{ Bell $^{*}$} & NHFM & $98.00(97.01-98.70)$ & 98.04 (96.90-98.74) & $98.00(97.33-98.33)$ & $14.14(12.91-16.33)$ \\
\hline & HFM & 95.24 (93.71-96.60) & 95.54 (94.00-96.75) & $95.33(94.33-96.00)$ & $21.60(20.00-23.80)$ \\
\hline \multirow[t]{2}{*}{ Gauss* } & NHFM & 97.95 (96.86-98.70) & 97.97 (96.92-98.72) & 98.00 (97.00-98.33) & $14.14(12.91-17.32)$ \\
\hline & HFM & 95.74 (94.24-96.90) & $96.00(94.63-97.18)$ & 95.67 (95.00-96.33) & $20.82(19.15-22.36)$ \\
\hline \multirow[t]{2}{*}{ Triangular* } & NHFM & 97.39 (96.13-98.58) & 97.40 (96.27-98.60) & 97.33 (96.67-98.00) & $16.33(14.14-18.26)$ \\
\hline & HFM & 96.05 (94.78-97.33) & 96.39 (95.12-97.44) & 96.33 (95.33-97.00) & 19.15 (17.32-21.60) \\
\hline \multirow[t]{2}{*}{ Trapezoidal ${ }^{*}$} & NHFM & 97.93 (96.76-98.68) & 97.99 (96.97-98.71) & 97.67 (97.00-98.33) & $15.28(12.91-17.32)$ \\
\hline & HFM & 94.56 (92.74-96.15) & 95.10 (93.42-96.50) & 94.67 (93.67-95.67) & $23.09(20.82-25.17)$ \\
\hline
\end{tabular}

Table 4. Sensitivity, specificity, accuracy and root mean square error values of hierarchical fuzzy models and nonhierarchical fuzzy models in test set of hypertension data set

\begin{tabular}{|c|c|c|c|c|c|}
\hline Function & Model & Sensitivity & Specificity & Accuracy & RMSE \\
\hline \multirow[b]{2}{*}{ Bell } & NHFM & 91.53 & 27.03 & 66.67 & 57.74 \\
\hline & HFM & 81.36 & 32.43 & 62.50 & 61.24 \\
\hline \multirow[b]{2}{*}{ Gauss } & NHFM & 94.92 & 16.22 & 64.58 & 59.51 \\
\hline & HFM & 94.92 & 10.81 & 62.50 & 61.24 \\
\hline \multirow[b]{2}{*}{ Triangular } & NHFM & 84.75 & 35.14 & 65.63 & 58.63 \\
\hline & HFM & 86.44 & 24.32 & 62.50 & 61.24 \\
\hline \multirow[b]{2}{*}{ Trapezoidal } & NHFM & 93.22 & 29.73 & 68.75 & 55.90 \\
\hline & HFM & 81.36 & 32.43 & 62.50 & 61.24 \\
\hline
\end{tabular}


Rule 27: If $\mathrm{BMI}_{\text {obese }}$ and $\mathrm{TG}_{\text {high }}$ and $\mathrm{FBG}_{\text {hyperglycaemia }}$ then GROUP hypertension

Rule Base in Hierarchical Fuzzy Models

$U_{1 i}(i=1,2,3)$ is to be the $i^{\text {th }}$ sub-category of the intermediate output $U_{1}$ then rules of HFMs are as follows:

Rule 1: If $\mathrm{BMI}_{\text {normal }}$ and $\mathrm{TG}_{\text {normal }}$ then $\mathrm{U}_{11}$

Rule 2: If $\mathrm{BMI}_{\text {normal }}$ and $\mathrm{TG}_{\text {high at limit }}$ then $\mathrm{U}_{11}$

Rule 3: If $\mathrm{BMI}_{\text {normal }}$ and $\mathrm{TG}_{\text {high }}$ then $\mathrm{U}_{11}$

Rule 4: If $\mathrm{BMI}_{\text {overweight }}$ and $\mathrm{TG}_{\text {normal }}$ then $\mathrm{U}_{12}$

Rule 5: If $\mathrm{BMI}_{\text {overweight }}^{\text {overweight }}$ and $\mathrm{TG}_{\text {high at limit }}^{\text {normal }}$ then $\mathrm{U}_{12}$

Rule 6: If $B M I_{\text {overweight }}$ and $\mathrm{TG}_{\text {high }}$ then $U_{12}$

Rule 7: If $B M I_{\text {obese }}$ and $\mathrm{TG}_{\text {normal }}$ then $\mathrm{U}_{13}$

Rule 8: If $B M l_{\text {obese }}$ and $T_{\text {high at limit }}$ then $U_{13}$

Rule 9: If $\mathrm{BMI}_{\text {obese }}$ and $\mathrm{TG}_{\text {high }}$ then $U_{13}$

Rule 10: If $U_{11}$ and $F B G_{\text {hypoglycaemia }}$ then GROUP control

Rule 11: If $U_{11}$ and $F B G_{\text {normal }}$ then GROUP control

Rule 12: If $U_{11}$ and $F B G_{\text {hyperglycaemia }}$ then GROUP control

Rule 13: If $U_{12}$ and $F B G_{\text {hypoglycaemia }}$ then GROUP control

Rule 14: If $U_{12}$ and $F B G_{\text {normal }}$ then GROUP

Rule 15: If $U_{12}$ and $F B G_{\text {hyperglycaemia }}$ then GROUP ${ }_{\text {hypertension }}$

Rule 16: If $U_{13}$ and $F B G_{\text {hypoglycaemia }}$ then GROUP hypertension

Rule 17: If $U_{13}$ and $F B G_{\text {normal }}$ then GROUP

Rule 18: If $U_{13}$ and $F B G_{\text {hyperglycaemia }}$ then GROUP ${ }_{\text {hypertension }}$

\section{Discussion}

There are a lot of researches on classification problems in which fuzzy models have been used. As being in many research fields, there are a lot of works on classification with fuzzy models built by health data sets in medicine literature too.

Resulting of examination of literature, it is seen that in most of the classification problems NHFMs are used. Karahoca et al. (22) aimed to compare the classification performances of non-hierarchical fuzzy logic and multinomial logistic regression methods by using age, waist/hip and glucose ratio variables. They divided 390-unit-data set into training (300 units) and test (90 units) sets. In order to build ANFIS structure they fuzzified age and glucose ratio variables that were crisp valued by dividing into three and five subcategories, respectively. They reported that RMSE of assigning diabetic individuals into "hypoglycaemic", "hypoglycaemia at low risk", "healthy", "diabetes at low risk" or "diabetic" classes with NHFM was $17.45 \%$ while this value was found to be $23.43 \%$ in multinomial logistic regression. In this way, they determined that non-hierarchical fuzzy logic method made better classification than multinomial logistic regression method. Ankişhan and Ari (23) aimed to make snore-related sound classification by nonhierarchical fuzzy logic method. For this aim, they divided sounds which were normal and related to sleep apnea into pieces, then calculated the entropy and energy of those sounds as independent variables of the model. They reported that the ANFIS structure they created constituted $97.08 \%$ of the accuracy of allocating individuals to 'snoring', 'sleeping' or 'silent' classes. Mahmoudi et al. (31) aimed to compare the performances of the ANFIS structure in classification of individuals into cancer types using a total of six microchip gene expression data sets for breast, blood, colon, prostate, lung and lymphoma cancers and the performance of the support vector machine, k-nearest neighborhood and classification and regression trees methods. They found that the highest classification performance among the models they created separately for all cancer data sets was mostly due to the non-hierarchical fuzzy logic method. In another study, Uçar et al. (24) aimed to use a shorter data mining method as an alternative to the medical diagnostic test for the diagnosis of tuberculosis disease and stated that they preferred ANFIS to estimate in what probability individuals carry the bacterial cause of tuberculosis in their body. They classified dependent variables as $0,0.25$, $0.50,0.75$ or 1.00 probability classes for this and reported that $97 \%$ of the classification success of the NHFM using the 20 most important variables among the 30 risk factors of the disease was found. Yang et al. (35) performed a classification study on brain signals, a total of 200 brain signals were recorded from electrical status epilepticus in sleep (ESES) patients and control subjects in 8-second segments with a 16-channel electroencephalogram device. In the study where each channel was used as an independent variable, two different entropies were calculated from 8-second segments and two NHFMs were constructed by building ANFIS structure. With these models created by using bell membership function, the individuals were divided into ESES or control classes with $89 \%$ and $82 \%$ accuracy respectively. Ziasabounchi and Askerzade (16) aimed to classify individuals with a NHFM using the Gaussian membership function according to their degrees of having cardiac disease. They selected age, chest pain 
type, cholesterol, maximum heart rate, resting blood pressure, glucose and electrocardiographic variables among independent variables in the Cleveland heart disease data set from the University of California artificial intelligence database, which consists of 303 units and 13 independent variables. In the fuzzification step of the HFM, they divided age, blood pressures at rest, cholesterol variables into three; and the maximum heart rate into two sub-categories. They then divided the data set into $80 \%$ (243 units) training and $20 \%$ (60 units) test data and reported that they classified the test data set with 15\% error and $92.3 \%$ accuracy with the classification model built in training set with $1 \%$ error. In our study, by using simulation and hypertension data set and different membership functions, HFMs as well as NHFMs were created and the classification performances of these models were compared according to sensitivity, specificity, accuracy, and RMSE criteria. By this comparison, it was found that NHFMs were better than HFMs.

In cases where the number of independent variables is large, hierarchical fuzzy logic method is proposed, which is achieved by combining smaller sized fuzzy sub-models. Since in the process of constructing fuzzy model with the best classification; the number of parameters that need to be adapted in the most appropriate way, which is also called the "dimension problem", increases as the number of independent variables increases. This causes both parameter complexity and time loss in the classification phase in the fuzzy inference process (5-8).

There are not many studies that use HFMs in the health field. Akbarzadeh-T and Moshtagh-Khorasani (36) conducted a test which was consisted of thirty questions and measured the ability of repeating the sentences, comprehending and matching names, written language qualification of 265 individuals who were aphasic. Because of the large number of independent variables, they pointed out that they aimed to classify aphasia species with an HFM. From the thirty independent variables in the first layer of the HFM, they constructed a fuzzy model with four rules using six interrelated variables that best described disease types, on the other hand; in the second layer using the outputs of the first layer and the four independent variables that they chose among thirty independent variables they created the second fuzzy model and classified aphasia types with $92 \%$ accuracy.
Amouzadi and Mirzaei (37) aimed to build HFM to make classification of the data sets whose dependent variables were categorical by using "breast cancer" data set which consisting of nine independent variables with 699 units; "pima" data set containing eight independent variables with 768 units, "wine" data set with thirteen independent variables and 178 units, "haberman" data set with three independent variables and 306 units and lastly "iris" data set with four independent variables with 150 units.

They reported that they preferred the hierarchical fuzzy logic method as the classification method in order to avoid the curse of dimensionality caused by a large number of independent variables and the length of the classification process time. They used as many layers as sub-categories that each independent variables had in the study and divided the membership functions they used in each layer into two to form the rule base. At the end of the study, they reported that they achieved a correct classification of $96 \%$ in the "breast cancer" data set, 76\% in the "pima" data set, 95\% in the "wine" data set, $77 \%$ in the "haberman" data set and 95\% in the "iris" data set. Shaeiri and Ghaderi (38) aimed to classify patients into types of cancers using gene expression data sets for blood, prostate and colon cancers. In order to do this, they first divided the cancer data set which consisted of 7129 genes of 72 patients into training (38 units) and test (34 units) sets and then classified patients in test data set into "acute myeloblastic leukemia" or "acute myeloid leukemia" classes with accuracy of $100 \%$; in addition to this, they used prostat data set which consisted of 12600 genes of 102 patients and classified patients into "tumor" or "normal" classes with $99.21 \%$ accuracy. They also reported that they had $98.84 \%$ accuracy of classification of patients into "normal" or "tumor" classes by creating a fuzzy model from the data set which contained 2000 genes of 62 units after dividing it into training and test sets. In our study, the effect of the number of independent variables used in both HFMs and NHFMs on the classification performance of the model was examined. For this purpose, it was observed that the performance of the classification of the model increases with the increase of the number of independent variables as a result of simulation using three and six independent variables. In addition, the classification performances of the models were found to approximate each 
other. However, with the increase in the number of independent variables, it was observed that the rule base expanded in both models. In simulation, when the number of independent variables increased from 3 to 6 ; the number of rules increased accordingly from 8 to 64 in NHFM; from 8 to 27 in HFM. In hypertension data set application, 18 rules were obtained in HFM while this number was 27 in NHFM. As a result of the analyses, it was determined that the classification performances of the fuzzy models depend on the distribution of data, the number of sub-categories of each of the independent variables has, the type of membership function to be used, the number of the independent variables to be modelled and correlation between them. Accordingly, histogram graphs of independent variables should be used in the fuzzification step. In cases where the distributions are highly intertwined, the model should be further refined by increasing the number of sub-categories, and the fuzziness should be tried to be eliminated. The extent to which fuzziness is eliminated should be determined from the overlapping regions in the drawn membership function graphs, and a model should be created using the membership function that gives the most appropriate result. Moreover, if the number of independent variables is too large, the variables associated with each other should be included in the same layer, then these layers must be combined to form an HFM. However, loss of information in transitions between layers of HFMs is a limitation of this method. It is predicted that increasing the number of independent variables and modelling the independent variables with high correlation level can prevent the loss of information due to the layers and thus the classification performance of the model will be better.

\section{Conclusion}

Health data contain many factors that cause diseases. When the diagnosis of a disease is made, which sub-category the values of the factors that cause diseases belong is and the interaction between the sub-categories are important. In this kind of data structures, fuzzy logic methods should be used, which is a method that allows the estimation of the output values by using the factors whose categories are transitive and the interactions of sub-categories of them. Particularly in data sets with large number of factors, HFM which allows the creation of smaller rule base by gathering highly correlated factors into the same layer should be used. In cases that the inference of which sub-categories of the factors interacted to each other are important for classification of the individuals as patient or control, then a NHFM should be used. It should be noted, however, that the number of factors or the number of sub-categories of them should be chosen so as not to constitute an extremely large rule base.

\section{Ethics}

Ethics Committee Approval: It was not taken. Informed Consent: It was not taken.

Peer-review: Externally peer-reviewed.

\section{Authorship Contributions}

Concept: I.K.Ö., M.T., Design: F.C., İ.K.Ö., M.T., Data Collection or Processing: F.C., I.K.Ö., Analysis or Interpretation: F.C., I..K.Ö., M.T., Literature Search: F.C., Writing: F.C., I..K.Ö.

Conflict of Interest: No conflict of interest was declared by the authors.

Financial Disclosure: The authors declared that this study received no financial support.

\section{References}

1. Buckley JJ, Eslami E. An Introduction to fuzzy logic and fuzzy sets. Springer-Verlag 2003; 285.

2. Zadeh LA. Fuzzy Sets. Information and Control 1965; 8: 338-53.

3. Altaş ï. Bulanık Mantık: Bulanıklılık Kavramı. Enerji ElektrikElektromekanik-3e. 1999; 62: 80-5.

4. Licata G. Employing fuzzy logic in the diagnosis of clinical case. Health 2010; 2: 211-24.

5. Brown M, Bossley KM, Mills DJ, Harris CJ, eds. High dimensional neurofuzzy systems: overcoming the curse of dimensionality. IEEE International Conference on Fuzzy Systems; 1995.

6. Raju GVS, Zhou J, Kisner RA. Hierarchical fuzzy control. International Journal of Control 1991; 54: 1201-16.

7. Emara H, Elshafei AL. Robust robot control enhanced by a hierarchical adaptive fuzzy algorithm. Engineering Applications of Artificial Intelligence 2004; 17: 187-98.

8. Chen Y, Peng L, Abraham A, eds. Programming hierarchical TS fuzzy systems. Proceedings of the 2006 International Symposium on Evolving Fuzzy Systems, EFS'06; 2006.

9. Jang JSR, eds. Input selection for ANFIS learning. IEEE International Conference on Fuzzy Systems; 1996.

10. Sivanandam SN, Sumathi S, Deepa SN. Introduction to fuzzy logic using. MATLAB 2007; 1-430.

11. Jang JSR, Sun CT, Mizutani E. Neuro-fuzzy and soft computing: a computational approach to learning and machine intelligence. Prentice Hall 1997; 614. 
12. Leondes CT. Fuzzy logic and expert systems applications. Academic Press 1998; 416.

13. Czogala E, Leski J. Fuzzy and Neuro-Fuzzy Intelligent Systems. Physica Verlag, Springer Science \& Business Media 2000; 194.

14. Ross TJ. Fuzzy logic with engineering applications. Wiley 2009; 585.

15. Canul-Reich J, Shoemaker L, Hall LO, eds. Ensembles of fuzzy classifiers. IEEE International Conference on Fuzzy Systems; 2007.

16. Ziasabounchi N, Askerzade I. ANFIS Based Classification Model for Heart Disease Prediction. Intenational Journal of Electrical and Computer Sciences. 2014; 14: 7-12.

17. Joo MG, Lee JS, eds. Hierarchical fuzzy control scheme using structured Takagi-Sugeno type fuzzy inference. IEEE International Conference on Fuzzy Systems; 1999.

18. Toosi AN, Kahani M, Monsefi R, eds. Network intrusion detection based on Neuro-Fuzzy classification. 2006 International Conference on Computing and Informatics, ICOCI '06; 2006.

19. Wei M, Bai B, Sung AH, Liu Q, Wang J, Cather ME. Predicting injection profiles using ANFIS. Information Sciences 2007; 177: 4445-61.

20. Ba-Alwi F. Knowledge Acquisition Tool for Learning Membership Function and Fuzzy Classification Rules from Numerical Data. International Journal of Computer Applications 2013; 64: 24-30.

21. Raut AS, Singh KR. Adaptive Neuro-Fuzzy Inference System For Anomaly-Based Intrusion Detection. International Journal of Research in Engineering and Applied Sciences 2014; 2: 27-36.

22. Karahoca A, Karahoca D, Kara A, eds. Diagnosis of diabetes by using adaptive neuro fuzzy inference systems. ICSCCW 2009 -5th International Conference on Soft Computing, Computing with Words and Perceptions in System Analysis, Decision and Control; 2009.

23. Ankişhan H, Ari F, eds. Snore-related sound classification based on time-domain features by using ANFIS model. INISTA 2011 2011 International Symposium on INnovations in Intelligent SysTems and Applications; 2011.

24. Uçar T, Karahoca A, Karahoca D. Tuberculosis disease diagnosis by using adaptive neuro fuzzy inference system and rough sets. Neural Computing and Applications 2013; 23: 471-83.

25. Güler I, Ubeyli ED. Adaptive neuro-fuzzy inference system for classification of EEG signals using wavelet coefficients. J Neurosci Methods 2005; 148: 113-21.

26. Bhattacharyya S, Basu D, Konar A, Tibarewala DN. Interval type2 fuzzy logic based multiclass ANFIS algorithm for real-time
EEG based movement control of a robot arm. Robotics and Autonomous Systems 2015; 68: 104-15.

27. Buyukbingol E, Sisman A, Akyildiz M, Alparslan FN, Adejare A. Adaptive neuro-fuzzy inference system (ANFIS): a new approach to predictive modeling in QSAR applications: a study of neurofuzzy modeling of PCP-based NMDA receptor antagonists. Bioorg Med Chem 2007; 15: 4265-82.

28. Arya V, Rathy RK, eds. An efficient Neuro-Fuzzy Approach for classification of Iris Dataset. ICROIT 2014 - Proceedings of the 2014 International Conference on Reliability, Optimization and Information Technology; 2014.

29. Liu M, Dong M, Wu C. A New ANFIS for Parameter Prediction With Numeric and Categorical Inputs. IEEE Transactions on Automation Science and Engineering 2010; 7: 645-53.

30. Azizi A, Ali AYB, Ping LW. Model development and comparative study of bayesian and ANFIS inferences for uncertain variables of production line in tile industry. WSEAS Transactions on Systems 2012; 11: 22-37.

31. Mahmoudi S, Lahijan BS, Kanan HR, eds. ANFIS-based wrapper model gene selection for cancer classification on microarray gene expression data. 13th Iranian Conference on Fuzzy Systems, IFSC 2013; 2013.

32. Wang LX. Analysis and design of hierarchical fuzzy systems. IEEE Transactions on Fuzzy Systems 1999; 7: 617-24.

33. Lee ML, Chung HY, Yu FM. Modeling of hierarchical fuzzy systems. Fuzzy Sets and Systems 2003; 138: 343-61.

34. Türe $M$, Kurt I, Yavuz E, Kürüm T. Comparison of multiple prediction models for hypertension (Neural network, logistic regression and flexible discriminant analyses). Anadolu Kardiyoloji Dergisi 2005; 5: 24-8.

35. Yang $Z$, Wang $Y$, Ouyang G. Adaptive neuro-fuzzy inference system for classification of background EEG signals from ESES patients and controls. Scientific World Journal 2014; 2014: 140863.

36. Akbarzadeh-T MR, Moshtagh-Khorasani M. A hierarchical fuzzy rule-based approach to aphasia diagnosis. J Biomed Inform 2007; 40: 465-75.

37. Amouzadi A, Mirzaei A, ed. Hierarchical fuzzy rule-based classification system by evolutionary boosting algorithm. 2010 5th International Symposium on Telecommunications, IST 2010; 2010.

38. Shaeiri Z, Ghaderi R. Genetic diagnosis of cancer by fuzzyrough gene selection and the complementary hierarchical fuzzy classifier. Biomed Mater Eng 2011; 21: 7-52. 